SAŠA PROPADALO, B.Eng.

E mail: spropadalo@yahoo.com

Ministry of Defence of the Republic of Croatia

Trg Kralja Petra Kresimira IV. 1, 10000 Zagreb, Croatia

DAMIR BEKAVAC, B.Eng.

E mail: damir.bekavac@gmail.com

ZORAN JAKŠIĆ, B.Eng.

E mail: zoran.jaksic@crocontrol.hr

Croatia Control Ltd.

Pleso bb, 10150 Zagreb-Airport, Croatia
Transport Logistics

Preliminary Communication

Accepted: May 10, 2011

Approved: Mar. 14, 2012

\title{
SPARE MODULES MANAGEMENT OPTIMIZATION OF AIRSPACE SURVEILLANCE SYSTEM
}

\begin{abstract}
This paper presents an application of Poisson distribution method for managing the optimal number of spare modules of the Croatian airspace surveillance system. Out of a large number of modules and electronic parts in operation, a set of 11 critical modules are identified which have experienced failures and replacements with identical modules in three years history data. Using Poisson distribution for the failure forecasting, maintenance planner can make optimal ordering of the critical spare modules for a following period by which is possible to avoid any backordering, spare module shortage and the most important operational shutdowns. The results were the creation of the Poisson model in predicting the failure rate of radar vital modules for sizing the initial stock of spare modules to be ordered along with other electronic equipment.
\end{abstract}

\section{KEYWORDS}

optimization, spare parts, Poisson distribution, forecasting, maintenance, reliability, non-repairable parts

\section{INTRODUCTION}

Computation about optimal number of spare parts in stock has been the goal of many researchers and has produced a wide variety of models. From the maintenance aspect, the focus of spare part models should be supporting the operation of a single unit or component, in this case airspace surveillance system, ensuring that the operational requirements are achieved. With the installation of the new Lockheed Martin FPS117 radar systems for the surveillance of the Croatian airspace the logistic model of the spare modules has become very important to ensure undisturbed continuous work of the system. The main characteristic of the airspace surveillance systems is their geographical dispersion on different locations by which the main- tenance actions become quite complicated if all steps are not closely planned and controlled. The considerations in this paper start from the assumption that, regarding the Poisson distribution for failure forecasting as well as regarding the field data, it is possible to define the model of optimal number of vital spare modules of the radar system by failure forecasting and computing the desired spare part stock level for a projected time.

The project will concentrate only on critical modules, eleven of them located in five identical radars connected in radar network. This does not mean that the author disregards the analysis of cheaper, less critical parts. Spare modules can be generally classified into non-repairable and repairable ones, and in this work only non-repairable will be in focus. Also, each failed module in radar network is replaced by a new identical one which is stored in the central warehouse.

Many models discussed in the literature assume that the demand for spares follows a Poisson process [1], where the failure (or replacement) rate for a population of $m$ components in operation follows a Poisson distribution with mean $m \lambda$, where $\lambda$ is the failure (or replacement) rate of an individual component. This assumption is less restrictive than it initially seems, as the number of identical units in operation is often relatively large. When this occurs, the superposed demand process for all the units converges rapidly to a Poisson process, independently of the underlying time to failure distribution [1] (if the failure distribution is exponential, the number of failures in an interval follows exactly the Poisson process, for any number of components). Because of this, the use of the Poisson distribution in spare parts inventory modelling has found wide application.

Determining the age at which an operating part in a radar system will fail and should be replaced with a 
new module has always been a maintenance problem. The age for such replacement should depend on the time-to-failure distribution of the modules. This can be better understood by examining the mortality characteristics of parts (Figure 1) which shows a typical time versus hazard rate (further in the text described as failure rate) curve for equipment. This is the "bathtub curve," which, over the years, has become widely accepted by the reliability community. It has proven to be particularly appropriate for electronic equipment and systems. The characteristic pattern is a period of decreasing failure rate (DFR) followed by a period of constant failure rate (CFR), followed by a period of increasing failure rate (IFR) [2].

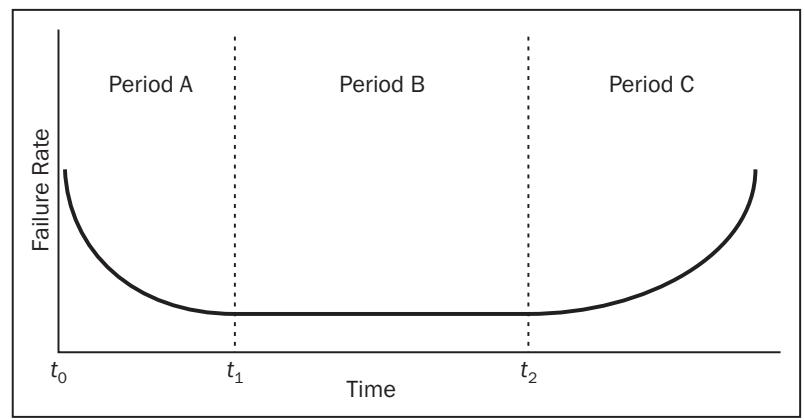

Figure 1 - Three types of mortality characteristics [2]

Period $A$ is the infant mortality (DFR) period characterized by an initially high failure rate [2].

Period $\mathrm{B}$, the useful life period, is characterized by an essentially constant failure rate (CFR). This is the period dominated by chance failures. Chance failures are those failures that result from strictly random or chance causes. They cannot be eliminated by either lengthy burn-in periods or good preventive maintenance practices. This CFR period is the basis for application of most reliability engineering design methods. Since it is constant, the exponential distribution of time to failure is applicable and is the basis for the design and prediction procedures spelled out in documents such as MIL- HDBK-217. The simplicity of the approach utilizing the exponential distribution, as previously indicated, makes it extremely attractive. Fortunately, it is widely applicable for complex equipment and systems. If complex equipment consists of many components, each having a different mean life and variance which are randomly distributed, then the system malfunction rate becomes essentially constant as failed parts are replaced [2].

Period $\mathrm{C}$, the wear-out period, is characterized by an IFR as a result of equipment deterioration due to age or use [2].

With installation of new Lockheed Martin FPS-117 radar systems for the surveillance of the Croatian airspace reorganization of the spare modules logistic model is necessary. Until now, the radar network maintenance model was, namely, adapted to older genera- tion radars and assumed the presence of the spare module units and spare parts at the radar position, i.e. at the radar the whole time of its operation. The considerations in this paper start from that, regarding the new radar manufacturer's data [3], as well as regarding the field data, it is possible to define the serving model with one central warehouse and a certain, optimal number of vital spare modules of the radar system by failure forecasting.

New spare modules for replacing the failed ones in a radar system are not located at the location of the very radar but rather form a part of the Serving Centre (central warehouse) and go to a certain radar position when there is need for it. The logistic office at the Serving Centre keeps data of the failed modules during all the time of operative radar work which is 8,760 hours per year. The project has used 3-year failure data of 11 vital radar modules which are replaced by new identical module after failure. The results of the calculation show the optimal number of the spare modules that has to be on stock during the following period of one year.

\section{RADAR MAINTENANCE}

The predicted airspace surveillance radar operation in peacetime conditions is $24 / 7$ which means 24 hours a day, seven days a week. The radar does not operate or is turned off from operative operation in case of preventive or corrective maintenance [4]. It is turned off in case of immediate danger from air, but this, as well as the possibility of radar destruction in case of war has not been presented in this project. Preventive maintenance is planned maintenance and it is planned for a certain time period. The frequency of inspections and maintenance works and the respective procedures are set by the radar manufacturer [3]. After a certain period of radar usage the user redefines the method and time necessary to serve the radar and adapts it to its own needs and requirements, all with the purpose of fewest possible interventions through corrective maintenance. Corrective maintenance refers to failure or malfunction of a part of the radar, its identification, diagnosis, repair and control. In practice, corrective maintenance is reduced, in the majority of cases (and thus described also in the model) to replacement of the malfunctioning module which later, depending on the defect and construction, is written off and replaced by identical new module.

\section{LITERATURE REVIEW}

Methods for forecasting and determining the resupply of wholesale, retail and manufacture stocks are easily found in books and inventory management courses. In such cases, the demand and the response 
time frequently have good adherence to the normal distribution, and time series methods are adequate for forecasting the demand. However, in the case of spare parts for maintenance, the problem is clearly different. When compared with retail items, spare parts are usually more expensive, of sporadic need and low consumption rate; the availability is critical (high stockout costs) [5].

Frequently, time intervals between failures are completely random, and many studies found in literature employ mainly Gamma and Poisson distributions to represent the demand for spare parts [6].

These distributions are associated with the known Poisson process characteristic of phenomena in which age or wear of the component does not affect the likelihood that it will fail, and also the fact that, given that a failure has just occurred, has no influence on the time elapsed until the next failure. A characteristic of the Poisson distribution (i.e. the probability distribution that, in a Poisson process, $x$ failures will occur in a given time interval t) which makes it easy to use, is that its average is equal to its variance and is a parameter that completely characterizes the distribution. Therefore, if the failure process has the characteristics of a Poisson process, it is enough to use the average demand of historical data to estimate the probability of any given number of failures to occur in any time interval [6].

The US Ministry of Defense issued a whole series of publications under the shared name MIL-HDBK which deal with reliability of electronic devices and systems. One of these is MIL-HDBK-338B "Electronic reliability design handbook \", DoD, USA and the MIL-HDBK-217 "Reliability Prediction of Electronic Equipment" DoD, USA.

After checking the forecasting methods used by a large number of electronic users and industries from audio manufacturers, telecommunications, up to radar manufacturer, it was found that all of them use Poisson distribution in the methodology for estimating the initial purchase of spare parts.

\section{POISSON DISTRIBUTION}

The Poisson distribution is the one of three discrete distributions, Binomial, Poisson and Hypergeometric that uses integers as random variables. This distribution is used quite frequently in the reliability analysis. It can be considered an extension of the binomial distribution when $n$ is infinite. In fact, it is used to approximate the binomial distribution when $n \geq 20$ and $p \leq 0.05$. If events are Poisson distributed, they occur at a constant average rate and the number of events that occur in any time interval are independent of the number of events occurring in any other time interval [2]. For example, the number of failures in a given time would be given by $f(x)=\frac{a^{x} e^{-a}}{x !}$

where $x$ is the number of failures and $a$ is the expected number of failures. For the purpose of reliability analysis, this becomes

$f(x ; \lambda, t)=\frac{(\lambda t)^{x} e^{-\lambda t}}{x !}$

where:

$\lambda=$ failure rate,

$t=$ length of time being considered,

$x=$ number of failures.

The reliability function, $R(t)$, or the probability of zero failures in time $t$ is given by:

$$
R(t)=\frac{(\lambda t)^{0} e^{-\lambda t}}{0 !}=e^{-\lambda t}
$$

or the exponential distribution.

In case of redundant equipment, $R(t)$ might be desired in terms of the probability of $r$ or fewer failures in time $t$. For this case

$R(t)=\sum_{x=0}^{r} \frac{(\lambda t)^{x} e^{-\lambda t}}{x !}$

\section{Failure Modelling}

Failure modelling is the key to reliability engineering. Validated failure rate models are essential to the development of prediction techniques, allocation procedures, design and analysis methodologies, test and demonstration procedures/control procedures, etc. In other words, all of the elements needed as inputs for sound decisions to insure that an item can be designed and manufactured so that it will perform satisfactorily and economically over its useful life [2].

Inputs to failure rate models are operational field data, test data, engineering judgment, and physical failure information. These inputs are used by the reliability engineer to construct and validate statistical failure rate models (usually having one of the distributional forms described previously) and to estimate their parameters [2].

\section{Series Configuration}

The simplest and perhaps most commonly occurring configuration in reliability mathematical modelling is the series configuration. The successful operation of the system depends on the proper functioning of all the system components. A component failure represents total system failure. A series reliability configuration is represented by the block diagram as shown in Figure 2 with $n$ components. Further, assume that the failure of any one component is statistically independent of the failure or success of any other. This is usually the case for most practical purposes. If this is not the case, then conditional probabilities must be used, which only increase the complexity of the calculations [2]. 


$$
\rightarrow R_{1}(t) \rightarrow R_{2}(t) \rightarrow R_{3}(t) \rightarrow R_{4}(t) \rightarrow \longrightarrow R_{n}(t) \rightarrow
$$

Figure 2 - Series reliability configuration [2]

Thus, for the configuration of Figure 2, under the assumptions made, the series reliability is given by

$$
R_{S}(t)=R_{1}(t) \cdot R_{2}(t) \cdot R_{3}(t) \cdot \ldots \cdot R_{n}(t)=\prod_{i=1}^{n} R_{i}(t)
$$

If, as we said before, a constant failure rate, $\lambda$, is assumed for each component, which means the exponential distribution for the reliability function, then it yields

$R_{S}(t)=e^{-\lambda_{1} t} \cdot e^{-\lambda_{2} t} \ldots e^{-\lambda_{n} t}=\exp \left[-\sum_{i=1}^{n} \lambda_{i} t\right]=\exp [-\lambda t]$

where

$\lambda=\lambda_{1}+\lambda_{2}+\ldots+\lambda_{n}=\frac{1}{\theta}$

Thus, the system failure rate, $\lambda$, is the sum of the individual component failure rates and the system mean life, $\theta=1 / \lambda$.

\section{DEFINITION OF TERMS}

Determining the number of spare components needed to protect a radar system operation from unallowed stock-out situations, it is necessary to define the criterion at which the stock level is "optimal". The criterion will not be the same for every application and every field of use, for example, in industrial practice cost minimization is typically preferred. Here, the main criterion is continually running of the airspace surveillance system with the minimum of system downtime [7].

When spare stock costs are irrelevant, the optimization criterion is usually shifted toward an inventory performance measure such as the probability of having a spare at hand when demand is generated. In this paper, we consider three criteria for optimization, defined as follows:

(i) Instantaneous reliability (of stock): this is the probability that a spare is available at any given moment in time. It is equivalent to the fraction of demands that can be immediately satisfied from stock at hand. In the literature, instantaneous reliability is commonly referred to as fill rate or less often as availability of stock or point availability in the long run. Fill rate is the proportion of failures for which a spare is available; = 1 - $P$ [Backorder]. Backorders occur when a failure occurs during lead time with no spares.

(ii) Interval reliability (of stock): this is the probability of not running out of stock at any moment over a specified period of time, such as one year. Since reliability has to be maintained for every moment during the interval, this criterion is more demanding than instantaneous reliability.

(iii) Availability: this is the percentage of non-downtime of a system/unit, considering only the lack of spare parts as cause for downtime (i.e. only extended downtime due to shortage of spares is considered in the calculations; all other sources of downtime, such as time to conduct regular or preventive maintenance of the system, are not included in this case).

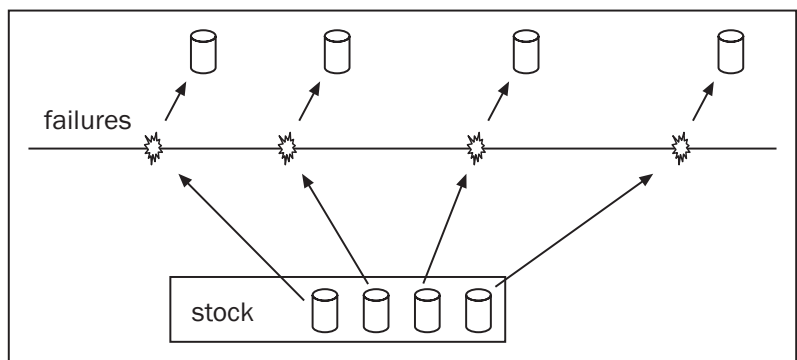

Figure 3 - Representation of non-repairable spares [7]

When the task of repair is extremely difficult (or physically impossible) or when the cost of repair exceeds the cost of purchasing a new component, the components are considered non-repairable. Thus, whenever a failure occurs a spare one from stock is installed and the removed component is discarded (Figure 3).

In this case, we are interested in determining the stock level required to ensure that no stock-outs occur (at a defined level of reliability) over a selected interval of time, typically the time required to receive a component on site, after an order has been placed (this is commonly called Lead-Time). For example, consider an operation in a remote location, where due to contract specifications spares for a component are delivered to the site every six months. In this case, the interval of interest will obviously be six months, as within that time frame no possibility exists to procure these components [7].

\section{SPARE MODULES CALCULATION}

Poisson distribution is used quite frequently in reliability analysis. This calculation estimate pretends failure rates are constant; this is the typical assumption for the Poisson spares computation. It also pretends the first failure in three years occurred at time zero. However, the conclusion that " $n$ " numbers of module " $N$ " failures will occur in six months is not true. The spares computation means that the Serving Centre should have " $n$ " spare modules " $N$ " to have a desired rate of probability of not having a stock outage.

This paper will show computation of the spare stock recommendation for the module $A$ in the radar 
Table 1 - Module A failures per years

\begin{tabular}{|c|c|c|c|c||}
\hline $\mathrm{A}$ & year 1 & year 2 & year 3 & Total \\
\hline \hline Failures & 6 & 2 & 3 & 11 \\
\hline
\end{tabular}

Table 2 - 3 years statistics of MTBF in hours for module A

\begin{tabular}{||c|c|c||}
\hline Failure & 3 years period & From the 1st failure \\
\hline \hline 1 & 1,248 & 0 \\
\hline 2 & 152 & 152 \\
\hline 3 & 1,424 & 1,424 \\
\hline 5 & 2,248 & 2,248 \\
\hline 6 & 976 & 976 \\
\hline 7 & 2,632 & 2,632 \\
\hline 8 & 904 & 904 \\
\hline 9 & 5,800 & 5,800 \\
\hline 10 & 3,088 & 3,088 \\
\hline 11 & 163 & 163 \\
\hline \hline
\end{tabular}

system based on 3-year data collection of the module failures (Table 1). Module A as an important, vital, electronic part of the radar system experienced 11 failures in 3 years period. Each module A after failure has been replaced by identical new one from the Central warehouse, delivered before from the manufacturer.

The calculation uses the original data on module Mean Times Between Failures (MTBF) for all five radars to make spares recommendations, for module A (Table 2). MTBF claims usually have little relation to reality, especially when failure rate is not constant. For manufacturer it is very important data by which he represents his product as a high reliability product. In nature, Time-to-Failure (TTF) plays a more important role. Time-to-failure (continuous) data are the most commonly observed type of reliability growth data. It involves recording the times-to-failure for the unit(s) under test. Time-to-failure data can be applied to a single unit or system or to multiple units or systems.

Computation (Table 3) shows cumulative timeto-failure (TTF), failure per hour. Also it calculates time-weighted average failure rate per hour which is 0.0003803 and the corresponding MTBF 2,630.

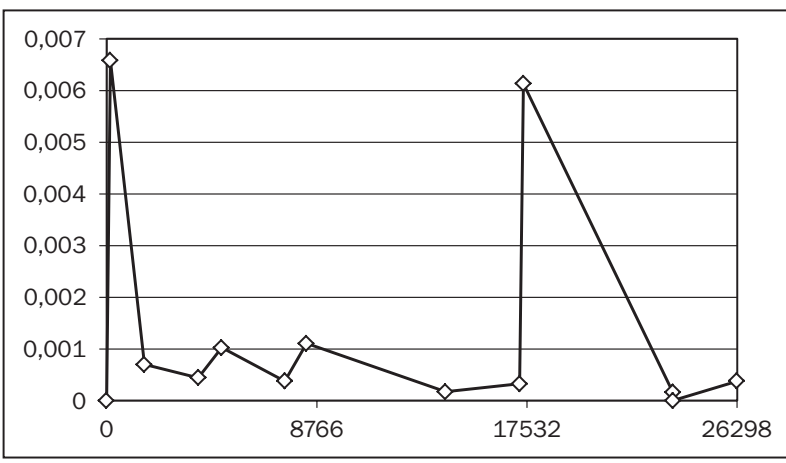

Graph 1 - Failure rate per hour
Table 3 - Computation of cumulative

TTF and failure per hour

\begin{tabular}{||c|c|c|c||}
\hline $\begin{array}{c}\text { Failure } \\
\text { No }\end{array}$ & $\begin{array}{c}\text { Time from } \\
1^{\text {st }} \text { failure }\end{array}$ & $\begin{array}{c}\text { Cumulative } \\
\text { TTF }\end{array}$ & $\begin{array}{c}\text { Failure } \\
\text { rate/hour }\end{array}$ \\
\hline \hline 1 & 0 & 0 & 0 \\
\hline 2 & 152 & 152 & 0.0065789 \\
\hline 3 & 1,424 & 1,576 & 0.0007022 \\
\hline 4 & 2,248 & 3,824 & 0.0004448 \\
\hline 5 & 976 & 4,800 & 0.0010246 \\
\hline 6 & 2,632 & 7,432 & 0.0003799 \\
\hline 7 & 904 & 8,336 & 0.0011062 \\
\hline 8 & 5,800 & 14,136 & 0.0001724 \\
\hline 9 & 3,088 & 17,224 & 0.0003238 \\
\hline 10 & 163 & 17,387 & 0.006135 \\
\hline 11 & 6,232 & 23,619 & 0.0001605 \\
\hline & & 23,619 & FALSE \\
\hline & & 26,298 & 0.0003803 \\
\hline & & & 2,630 \\
\hline
\end{tabular}

Those data are the first step in spare stock recommendation.

By using Poisson spares stock level recommendation the user can calculate the average number of desired stock of the spare part by entering the lead time. Lead time (usually in hours) represents the time required to receive a component on site and in this specific system that time is 6 months or in hours: 4,380 hours. Here we must assume that modules are produced outside of the user country and that modules have usually been made by direct ordering. By entering different lead times it is possible to make computation for different time periods by user demands. The following data that must be input are fill rate. To achieve high percent of reliability the fill rate should be at a high level.

Table 4 - Poisson spares stock level recommendation

\begin{tabular}{||l|c||}
\hline \hline LeadTime & 4,380 \\
\hline FillRate & 0.90 \\
\hline Average & 3 \\
\hline
\end{tabular}

The result of Poisson spare stock recommendation for input values is to order and to have in stock three spare modules A to keep any back-orders or spare module A missings (Table 4). By this the radar system will keep high reliability and availability in a six-month period of work.

\section{CONCLUSION}

The main objective of this paper is to present an alternative method for use in sizing and optimizing the management of the stock parts as a very important 
role in the maintenance of the airspace surveillance system like this one, consisting of 5 radars located on different locations across the country.

Results in this study have shown that for module A the desired stock level are three spare modules for the following period of six months which has been taken as an optimal time to reach the desired module from the manufacturer. The same computation has been done for other modules, but they have not been covered by this paper. The obligation of the serving centre is to make sure to order and to have in stock the computed number of spare modules, by which their work has been optimized along with the stock level of the spare modules. By this method the Service Centre can make stock-level computations for every electronic part of the system by following their failures and TTF times during the whole period of work.

The critical information which must be followed, recorded and input into computation along with the desired fill-rate is TTF (time-to-failure). In the case studied, the initial stock of replacement parts was dimensioned according to the failure rate informed by the final user, by the real life data from the 3-year record data. Followed and recalculated failure rate is an essential forecast parameter and a description of the item behaviour under real life conditions.
SAŠA PROPADALO, dipl.ing.

E mail: spropadalo@yahoo.com

Ministarstvo obrane Republike Hrvatske

Trg Kralja Petra Kresimira IV. 1, 10000 Zagreb, Hrvatska

DAMIR BEKAVAC, dipl.ing.

E mail: damir.bekavac@gmail.com

ZORAN JAKŠIĆ, dipl.ing.

E mail: zoran.jaksic@crocontrol.hr

Hrvatska kontrola zračne plovidbe d.o.o.

Pleso bb, 10150 Zagreb-Zračna luka, Hrvatska

\section{SAŽETAK}

\section{ODREĐIVANJE OPTIMALNOG BROJA REZERVNIH MODULA RADARSKOG SUSTAVA}

U radu je prikazana uporaba Poissonove distribucije koja se može koristiti za predviđanje optimalnog broja rezervnih modula radarskog sustava proizvedenog u SAD-u. Među velikim brojem elektroničkih dijelova i sklopova, identificirani su 11 vitalnih, kritičnih, modula koji su tijekom promatrane 3 godine rada pretrpjeli kvar čime dolazi do isključivanja $i$ prestanka rada sustava. Korištenjem Poissonove distribucije za predviđanje kvarova, korisnik sustava može napraviti optimalnu narudžbu kritičnih rezervnih modula za naredni period čime je moguće izbjeći nedostatak rezervnih modula, te ono najbitnije dugotrajno isključivanje sustava. Rezultat rada je kreiranje Poissonova modela za izračunavanje količine pričuvnih modula koji se trebaju naručiti zajedno sa ostalom elektroničkom opremom. Uporaba modela je moguća za sve elektroničke dijelove i sklopove koji se koriste u sustavu.

\section{KLUČNE RIJEČI}

optimizacija, rezervni moduli, logistika, Poissonova distribucija, predviđanje kvarova, održavanje, nepopravljivi dijelovi

\section{LITERATURE}

[1] Cox, R.: Renewal Theory, Methuen, London, 1962

[2] MIL-HDBK-338B, Electronic reliability design handbook, DoD, USA, 1998

[3] Web site, http://www.lockheedmartin.com/html, 26.04.2011

[4] Crnković, T.: Optimizacija logističke potpore izdvojenih radarskih postaja za nadzor zračnog prometa, Fakultet prometnih znanosti, Zagreb, Master's Thesis, 2008

[5] Neves, G., Diallo, M., Lustosa L.J.: Initial Electronic Spare Parts Stock and Consumption Forecasting, Department of Industrial Engineering, Rio de Janeiro, 2008

[6] Croston, J.D.: Forecasting and Stock Control for Intermittent Demands. Operational Research Quarterly, Vol.23, No 3, pp. 289-303, September 1972

[7] Louit, D., Pascual, R., Banjevic, D., Jardine, A.: Optimization model for the critical spare parts inventoryreliability approach, Toronto, 2010 